\title{
Anji Case, Zhejiang Experience, and China Approach of Rural Revitalization
}

\author{
Xiaoyan Zhang ${ }^{1}$ Shu Luo ${ }^{2}$ Jiankang Zhang ${ }^{3 *}$ \\ 1, 2, 3 School of International Economy \& Tourism Management, Zhejiang International Studies University; Hangzhou \\ Zhejiang, China \\ ${ }^{*}$ Corresponding author. Email: zhangjk@zisu.edu.cn
}

\section{ABSTRACT}

Villages in Zhejiang province based on the practice of the strategy of rejuvenating, Yu village Anji county as a typical case, analysis in advancing in Anji county, Zhejiang province of the measures and the beautiful rural construction mode, sum up the experiences of Zhejiang province reform and to promote China's rural revitalization of the reference model, the solution of the "three rural problems" for the world to provide solutions in China.

Keywords: Yu Village Anji County, Rural revitalization, Zhejiang experience, Chinese approach

\section{乡村振兴之安吉案例、浙江经验与中国方案}

\author{
章晓燕 1 罗舒 2 张健康 $3^{*}$ \\ 1, 2, 3 浙江外国语学院国际经济与旅游管理学院, 杭州, 浙江, 中国 \\ *通讯作者, 邮箱: zhangjk@zisu.edu.cn \\ 摘要 \\ 本文立足于浙江省乡村振兴战略的实践，以安吉余村为典型案例，分析浙江安吉县在推进美丽乡村建设中的措 \\ 施和形成模式，总结浙江省的改革经验，为促进中国的乡村振兴提供借鉴范本，为世界 “三农问题” 的解决提 \\ 供中国方案。
}

关键词: 安吉余村 乡村振兴 浙江经验 中国方案

\section{1. 前言}

浙江省是中国改革开放的先行地和重要窗口, 为 了相应中共十九大所提出的乡村振兴战略, 加快推进 农村现代化进程决胜全面建成小康社会, 浙江省基于 习近平总书记 “两山理念” 指引下进行乡村治理改革 的伟大实践, 并发表各类指导性文件推动乡村振兴稳 步实施, 于各个方位规范浙江省乡村产业、文化、人 才、生态环境等的全面协调可持续发展。2020 年 3 月 底, 习近平总书记为浙江省赋予 “重要窗口” 的重要 地位和全新使命。浙江省在乡村振兴的战略背景之下, 牢固树立 “两山理念”, 持续推进 “千万” 工程, 全面 深化各项改革, 努力将浙江建设成乡村振兴的先行区, 为中国美丽乡村提供浙江范本。

\section{2. 浙江安吉的乡村振兴史}

\section{1. 变革探索阶段: 转变思路, 打造生态先 行}

安吉县地处浙北山区, 原本经济发展落后, 为了 改善当地经济环境, 安吉县选择大力发展重工业, 兴 办化工厂、水泥厂等, 此举造成经济与生态严重对立。 2000 年起, 安吉发展进入变革探索阶段, 2003 年开 始, 安吉在整治环境的同时, 不断地健全生态环境综 合治理的机制，整治村庄人居环境，并对乡村基础设 施进行完善, 逐步形成安吉乡村治理体系。2005 年安 吉成为“两山”理论的发源地, 全国首批生态县之一。 


\section{2. 快速发展阶段：发挥优势，打响品牌战 略}

2006 至 2010 年，安吉利用地方资源优势，实施 品牌战略, 推动乡村建设进入快速发展阶段, 打响了 安吉“中国竹乡”“中国白茶之乡”等名号。安吉还立 足生态优势创新绿色发展思路, 积极推进本县一二三 产业的全方位融合，如：将曾经的荒山 “黄泥岗” 发 展成集观赏、游乐等诸多项目于一体的著名景区 “中 南百草园”。如今中南百草园创造的旅游收入近两个 亿, 带动了周边百家农家乐的发展, 促进了农民增收, 真正地实现了乡村经济的可持续发展。

\section{3. 升级示范阶段: 科学规划, 形成规范标 准}

安吉以中国美丽乡村建设为契机, 在保护生态环 境的基础之上, 推进乡村治理和乡风建设, 依托优势 农业资源, 突出乡村品牌, 实现三产联动, 先一步走 上了 “产业兴、农村美、农民富” 的道路。其乡村建 设的模式是浙江省乡村治理的范本。2015 年, 浙江安 吉起草的《美丽乡村建设指南》从地方规范上升为国 家标准, 自此, 乡村振兴的安吉模式成为中国美丽乡 村建设的地方范本, 这表明安吉的乡村治理已经进入 升级示范阶段。

\section{3. 浙江安吉乡村振兴的余村案例}

\section{1. 余村乡村振兴艰辛起步}

上世纪末, 国家加快城市建设, 对工业生产的原 材料需求旺盛, 多数农村都在走“工业强县”的道路。 安吉余村依靠得天独厚的石矿资源, 大力发展 “石头 经济”, 开山采石, 村民收入得到大幅度提升, 但这样 靠山吃山的发展模式严重破坏了余村的生态环境: 工 业污水排入河流、粉尘漫天排放, 甚至还严重危害到 了村民的身体健康。这样牺牲生态而发展经济的模式 带来的恶果逐渐让余村人们开始反思, 并寻求破解污 染困境的新强县之道。2003 年起, 余村两委陆续关停 矿山, 下定决心转变余村经济的发展模式, 然而这样 的举动却造成了半数村民的失业, 村集体收入的骤然 下降, 余村的生态治理遭受到了前所未有的危机, 也 令村干部动摇了转型发展的信心。

\section{2. 余村改革的历史转折}

2005 年习总书记至余村调研时, 前瞻性地发表了 “绿水青山就是金山银山” 的著名论断, 点明了未来 余村的前进道路, 坚定了余村两委走生态优先的发展 信念。此后余村坚定不移践行生态优先的思路, 首先 即是护山育林, 注重当地自然资源和优美风光的保护, 深入开展 “三改一拆” “五水共治” 等行动, 建立排 污机制, 推进河道整治等同时做好村庄的区域规划, 开展垃圾分类等, 营造干净整洁的乡村环境等, 做好
生态修复工作; 其次, 余村利用好生态环境优势, 开 发绿色农业发展方式, 大力发展山水旅游观光业和以 农家乐为主的休闲体验式经济, 打造 “休闲余村” 品 牌，不仅促进了农民增收，更提高了绿色经济在生产 总值的比重, 谱好了 “生态建设” 的文章; 另外, 余 村格外注重村民生态理念的培育, 将 “两山理念” 融 入到乡村治理和乡风文明的建设中, 例如开办文化礼 堂, 评选美丽家庭、道德模范等, 不仅调动了村民参 与美丽乡村建设的积极性主动性, 更进一步提升了村 民的文化素质，做好了社会主义核心价值观的传播。

\section{3. 余村成为新农村示范点}

余村在走上 “绿水青山” 的致富之路的同时, 也 注重乡村治理体系的升级和完善。余村创新基层治理 方式, 以党建为核, 明确各项职责, 发挥支部带头的 标杆作风，同时借鉴高桥村的 “三治” 机制，在群众 自治上，规范民主决策，设立议事会等民主组织; 在 法治层面, 设立法律顾问等, 确保相关事宜符合法律 制度, 并制定村规民约等规范村民行为; 在德治层面, 设立道德评议会，评选模范标兵等等，余村根据自己 的地方特色，深入推进了 “三治融合”; 余村还加快农 村基础设施的完善，创建公共文化场所和休闲娱乐中 心，举办多种多样的晚会活动等，不断提升乡民生活 的幸福感和使命感。十五年来, 余村创新生态发展路 径, 将 “两山理念” 融入构建共享共建共治的治理体 系中, 打造 “8 个村” 的工作为抓手, 推动余村从靠 山吃山切实转变成了依山富山, 颠覆了传统的农村发 展模式, 成为了新农村建设的优秀模版。2020 年习近 平总书记再次来到余村, 对余村这十五年来的发展做 出了充分的肯定, 指明余村现在已经在全国起到示范 作用。

\section{4. 乡村振兴之浙江经验: 以安吉案例为源 点}

\section{1. 浙江经验概括: “两山三治” 的优秀模版}

乡村振兴的浙江经验以安吉案例为源点, 其经验 是 “两山理念” “三治融合” “党建为核”的有机统一, 基本内涵可以归纳为:一是以党组织为领导，深入挖 掘 “两山” 理论的价值内涵, 结合自身特点, 形成富 有生态底蕴的发展新模式, 二是在乡村治理中吸纳借 鉴高桥村的乡村治理经验：坚持自制法治德治 “三治 融合”，形成一套独特的乡村治理体系。两条主线的 农村改革带领安吉余村走上了一条经济发展与生态 保护双赢的绿色发展道路, 其成为农村示范点的建设 成果显示了习近平 “两山” 理论实践的伟大意义。以 余村的改革实践为基础凝练而成的余村经验，始终坚 持自治法治德治 “三治” 相结合，深入推进新时代乡 村建设, 以支部带村、发展强村、民主管村、依法治 村、道德润村、生态美村、平安护村、清廉正村等 “八 个村” 建设为抓手加强乡村治理工作, 是新时代 “枫 桥经验”的升华。 


\section{2. 浙江经验深度优化：理论深化保持先进 性}

浙江经验具体可以命名为 “余村经验”。“余村 经验” 的两点特色: 一是基于 “两山理念” 的生态发 展模式, 二是鉴于 “三治融合” 的乡村治理模式。这 两点特色不仅是新时代下对枫桥经验的传承与创新, 更是吸收了全国各地乡村治理的成功做法, 是各地乡 村治理的“集大成者。” 新时代下需要对余村经验进 行更精确的凝练和更深层次的优化，处理好“八个村” 建设的内在关系, 对比借鉴各地有效实践, 总结出乡 村治理的共性思路，才能保持好 “余村经验” 的先进 性与进步性。2018 年 9 月 7 日, 乡村治理 “余村经 验” 研讨会召开, 这是 “余村经验” 正式进入理论标 准化的重要契机, 通过此次研讨会, 政府部门联合专 家学者对余村经验进行探讨提炼, 对其形成的理论体 系进行完善总结, 余村经验由此在宏观的历史视角和 全新的现实层面进行了深度优化, 为日后余村经验在 地域上的横向扩散和应用提供了理论依据。

\section{3. 浙江经验广度扩散: 从 “地方经验”上 升为 “全国标准”}

浙江的 “余村经验” 不仅仅是 “地方经验” 更是 经得起实践检验的 “全国标准”, 当经验升级为 “标 准”, 就具有了指导实践的意义。2018 年, 安吉县以 “余村经验” 为原本, 发布了《乡村治理工作规范》, 余村经验经历了概括总结到理论深化再到广度扩散 的内在逻辑。迈入新时代, 我国生态文明建设进入了 新层次, 余村作为新农村的示范点、“两山理念” 的诞 生处, 其建设经验更值得复制和借鉴。同年习近平总 书记对《新时代乡村治理的 “余村经验”》做出批示, 中宣部调研组据此来到安吉余村实地调研, 通过考察 和报告的方式, 推动 “余村经验” 在全县域内广泛传 播。而余村作为乡村治理的样本, 通过团体参观学习, 政治经验交流等方式, 推动余村经验进入中央层面视 野。2019 年 3 月 8 日, 湖州市政府出台了《关于全面 推广 “余村经验” 大力提升乡村治理现代化水平的实 施意见》, 以市委一号文件的形式, 在全市范围内全 面推广 “余村经验”。至此, 市域内各个地方广泛吸收 了 “余村经验” 的精髓, 以 “八个村” 建设为抓手进 行乡村治理建设, 自此“余村经验”在各地深深扎根。

“余村经验” 就是 “浙江经验” 的代表和缩影, 是浙江省推进实施乡村振兴战略的智慧结晶, 也是中 国建设美丽新农村的先进示范。以余村为例的安吉模 式折射出浙江在美丽乡村的建设中, 始终坚持统筹规 划总体布局在先, 探索出以产业振兴为基础, 以生态 文明为前提, 以人民富裕为目标, 以城乡互促为重点, 以乡风文明为底蕴, 以规范治理为手段的科学改革思 路。浙江省坚持实施乡村产业振兴战略, 全面启动农 业农村现代化改革, 推动产业间的纵深交叉融合; 贯 彻 “两山理念” 在美丽乡村建设中的实施, 系统推进 生态环境的保护和修复, 同时加大乡容乡貌的治理整
改, 打造山水秀美干净整洁的新农村; 坚持乡风文明 为保障, 注重农民素质的提升, 传承发扬优秀的民俗 文化, 形成文化建设与乡村建设互促互进的新格局; 创新基层管理形式，加快构建 “三治融合” 的规范治 理体系, 形成国家标准, 构建有序管理有效治理的现 代化新农村。

\section{5. 乡村振兴的中国方案：破解 “世界之 问” 的有效之道}

\section{1. 改革开放的历史沿革：多元共治是政治 发展所趋}

从战略层面来讲, 国家深入推进乡村振兴战略, 从现实层面来看, 浙江省现代化、工业化进程的加快, 从情感层面来说, 乡村是在工业喧器中的最后情感寄 托, 因此乡村振兴是现实所趋。中国的乡村治理一直 以两大目标为指引: 一是将农民变成真正的乡村治理 主体, 二是实现乡村治理的现代化。这两大目标从两 个方面探讨了中国乡村治理所存在的问题和前进的 方向。中国的乡村治理体制变革困难, 直到从 1978 年 开始农村体制改革才改变了这一状况，农村政治生活 的主体转变为农民本身, 多元化共治成为可能, 村民 自治成为乡村治理的制度基础, 加快了乡村治理的现 代化进程。上世纪中期以来，中国的农村政治发展一 直都处于国家政治发展规划体系之下, 决定了中国乡 村治理必然与国家政治发展分不开，中国特色社会主 义发展道路很大程度上决定了乡村治理发展进程, 从 而走出了一条具有鲜明国家特色的中国乡村治理之 路。正因如此, 中国的乡村治理离不开当代中国的国 家治理进程, 离不开当代中国坚定不移的发展道路, 离不开中国的农村政治发展过程。

\section{2. 新时代的现实视角: 乡村振兴是全面复 兴刚需}

党的十九大报告指出，“三农”问题是关乎国计民 生的根本性问题，必须坚持把解决好 “三农” 问题作 为全党工作重中之重。必须站在统筹城乡发展的角度 上看待 “三农” 问题, 以新时代新发展理念为重要遵 循, 对高质量发展要求进行全方面落实, 走具有中国 特色的社会主义乡村振兴道路。为了合理有序地推进 乡村建设的进程，中共中央、国务院于 2018 年 9 月 份印发了《乡村振兴战略规划 (2018-2022 年)》。《规 划》依据习近平总书记关于 “三农” 工作的重要论述 为指导, 根据乡村振兴的阶段性要求进行分步谋划, 细化落实阶段性工作中的重难点, 全方面部署阶段性 工作中各项重大计划和重大行动, 确保乡村振兴战略 落到实处。2021 年 2 月 21 日, 《中共中央国务院关于 全面推进乡村振兴加快农业农村现代化的意见》发布, 这是 21 世纪以来中国第 18 个指导 “三农” 工作的中 央一号文件, 确保乡村振兴工作稳步实施。 


\section{3. 中国方案下的创新实践: 治理工作取得 卓越成效}

浙江省坚定不移地依据八八战略的引导，并结合 新时代乡村振兴战略的伟大实践, 助推中国乡村振兴 的创新发展, 为破解世界之问提供了有效之道。浙江 乡村治理的所尝试的实践和所获得的成果是中国逐 步推行乡村振兴战略的成果展现, 也是中国乡村振兴 创新成果的个性体现, 为乡村治理提供了中国方案。 这个方案有三个重点,一是在顶层设计方面予以加强, 完善乡村治理基层法律规划体系。小到余村治理，大 到国家战略, 建立多层级的政策规划体系, 因地制宜 深入地方实践。二是要推动各经济、人员、生态等多 要素的融合发展, 推动经济建设与生态环境保护相平 衡、缩小城乡发展差距、融合传统乡风民俗与先进文 化等等, 走全面协调可持续的乡村建设发展道路。三 是要尊重农民的主体地位, 激发农民参与乡村治理的 热情度和积极性, 集中民智, 推动乡村治理多元化, 把握好实现乡村治理的目标与满足乡村发展内在需 求相统一。为全面实现乡村振兴, 2003 年浙江省提出 面向未来发展的八项举措, 缩小城乡差距, 同时立足 于浙江省的生态环境优势, 为打造 “绿色浙江” 奠定 基础。为实现以上战略目标, 推动乡村振兴, 建设生 态强省, 浙江省着力推进 “千万” 工程, 开启环境污 染整治行动, 成功实现 “两山” 的转化, 开启美丽乡 村新篇章。

\section{6. 结论}

“绿水青山也是金山银山” 是经得住实践检验的, 在生态基础之上进行乡村治理的有效途径, 是当代乡 村治理的价值取向。它不仅代表了中国乡村治理的先 进水平, 同时也是为破解当代世界之问提供了有效之 道。由党建为核, “两山” 引领, “三治” 融合的余村 经验, 为地方乡村治理提供有效范例, 到余村经验广 泛传播上升至乡村治理的地方标准, 再到交出乡村治 理“中国方案”, 是中国乡村振兴路途中重要的一环, 为我国乡村振兴提供了巨大推动力。

\section{致谢}

本文为第十七届 “挑战杯” 全国大学生课外学术 科技作品竞赛作品的《浙江经验・重要窗口: 乡村振 兴之安吉案例》的阶段性成果之一。

\section{REFERENCES}

[1] Hu Z. (2020)"Yu Village Experience" in Rural Governance: Value, Diffusion and Deepening [J]. Jiangnan Forum, 2020, (02): 12-14.

[2] Some opinions of the CPC Central Committee and the State Council on adhering to the priority development of agriculture and rural areas to do a good job of ' agriculture, rural areas and farmers ' work [J]; bulletin of the State Council of the People ' s Republic of China ; 2019 ( 07 )

[3] Mei ZC. (2019) Path analysis of "agriculture, rural areas and farmers" work [J]. Energy, 2019(4):45-45.

[4] Zhang J, Wang WX. (2019) Theoretical Origin, Basic Model and Experience of Practice of "Two Mountains Theory" in Zhejiang Province [J]. Theoretical Observation,2018(08):57-61.

[5] Gao QC. (2019) Practice, Significance and Limits of Local Standards for Rural Governance: A Case Study of Anji County, Zhejiang Province [J]. Journal of Gansu University of Political Science and Law,2019(03):12-21.

[6] Shen Y. (2019) Rural Governance Experience of Zhejiang Province in the Context of Rural Revitalization Strategy in the New Era [J]. Journal of the Party School of Hangzhou Municipal Committee of CPC,2020(01):89-96.

[7] Huang Q, Wen LY. (2019) Study on the Mechanism of "Three Governance Integration" on the Good Governance of Rural Areas [J]. Journal of Guangxi Cadre Institute of Political Science and Law,2019,34(01):15-19. 